\title{
Going to the source: role of the invasion pathway in determining potential invaders
}

\author{
Marjorie J. Wonham ${ }^{1,2, *}$, William C. Walton ${ }^{2,3}$, Gregory M. Ruiz ${ }^{2}$, \\ Annette M. Frese ${ }^{2,5}$, Bella S. Galil ${ }^{4}$ \\ ${ }^{1}$ Williams College - Mystic Seaport Maritime Studies Program, PO Box 6000, Mystic, Connecticut 06355, USA \\ ${ }^{2}$ Smithsonian Environmental Research Center, PO Box 28, Edgewater, Maryland 21037, USA \\ ${ }^{3}$ Horn Point Laboratory, University of Maryland, Cambridge, Maryland, 21613 USA \\ ${ }^{4}$ Israel Oceanographic and Limnological Research, Ltd., Tel Shikmona, PO Box 8030, Haifa, Israel \\ ${ }^{5}$ Biology Department, MS33, Woods Hole Oceanographic Institution, Woods Hole, Massachusetts 02543, USA
}

\begin{abstract}
Biological invasions are an increasing agent of change in aquatic systems, and ballastwater transfer in ships is a leading pathway of these invasions. During sequential stages of ballast transfer (uptake, transport, and release), the density and diversity of the plankton assemblage is selectively filtered, determining the pool of potential invaders. Understanding taxon-specific patterns of mortality along the invasion pathway is key to understanding and predicting successful invasions. We quantified taxon-specific trends in plankton mortality during a $16 \mathrm{~d}$ trans-Atlantic ballast water voyage. In the ballast tanks, we collected a miminum of 50 live taxa. Over $50 \%$ of taxa and $>98 \%$ of organisms collected in initial samples were not detected at the end of the voyage. No ballasted organisms survived experimental transfer to coastal harbor water. We suggest that the invasion success of a particular taxon may be predicted both by high density at the end of a voyage (which is comparatively easy to measure) and by low mortality during a voyage (which may indicate good body condition, but is harder to measure). These 2 predictors were not, however, correlated across taxa. Midocean exchange, the most widely used method for reducing ballast-mediated invasion risk, alters the pool of potential invaders. In an experimental test of mid-ocean exchange, 93 to $100 \%$ of the coastal water and 80 to $100 \%$ of the coastal organisms were removed. However, the total density and diversity of plankton in the ballast tanks increased significantly following exchange and in laboratory experiments ocean water was not lethal to coastal organisms.
\end{abstract}

KEY WORDS: Ballast-water transport · Nonindigenous species · Plankton $\cdot$ Invasion success $\cdot$ Risk reduction $\cdot$ Mid-ocean exchange $\cdot$ Shipping

\section{INTRODUCTION}

Biological invasions by nonindigenous species are an increasing agent of global change (Carlton 1989, Williamson 1996, Cohen \& Carlton 1998, Parker et al.

\footnotetext{
${ }^{*}$ Present address and corresponding author: University of Washington, Department of Zoology, PO Box 351800, Seattle, Washington 98195-1800, USA.

E-mail: mwonham@u.washington.edu
}

1999, Wilcove et al. 1998), leading to local alteration of ecological processes and regional homogenization of communities (Elton 1958, Carlton 1989, 1999, Ruiz et al. 1997, 2000). Understanding and predicting invasions requires understanding the role of the invasion pathway in determining potential invaders (Carlton 1996, Vermeij 1996). Here, we focus on a particularly well-defined pathway, ballast-water transport in commercial vessels, and quantify the selective processes that filter the pool of potential invaders. 


\section{Ballast-water transport}

One of the largest pathways of marine introductions today is ballast-water transport along commercial shipping routes (Carlton \& Geller 1993, NRC 1996, Carlton 1999). Ballast water is ambient water loaded into ballast tanks of commercial vessels for trim and stability. A typical bulk cargo vessel may load ballast water while unloading cargo, and discharge that ballast water en route or while loading cargo in the next port. In this manner, dense and diverse assemblages of zooplankton (Carlton \& Geller 1993, Smith et al. 1999, Gollasch et al. 2000), phytoplankton (Hallegraeff \& Bolch 1991, Subba Rao et al. 1994), fish (Wonham et al. 2000) and protists (Galil \& Hülsmann 1997), are continuously being transferred within and among ocean basins.

For organisms to be introduced successfully via ballast-water transport, they must pass through a series of stages (Carlton 1985, 1996). Briefly, potential invaders must (1) survive ballasting into a ship's tank; (2) survive the voyage; and (3) survive discharge into the recipient port. At each stage, species are filtered out of the ballasted assemblage by abiotic and biotic sources of mortality. The selectivity of these mortality sources determines the final abundance and diversity of potential invaders delivered to a recipient port (Carlton 1985, 1996, Smith et al. 1999, Lavoie et al. 1999).

Sources of mortality at each stage are poorly understood. The selectivity of stages 1 and 3, plankton uptake and release, is for the most part undescribed (Carlton et al. 1982). Somewhat more is known about stage 2 , the ballast voyage, where heavy mortality may occur (Carlton et al. 1982, Rigby \& Hallegraeff 1994, Lavoie et al. 1999, Gollasch et al. 2000). Some taxa clearly survive better than others (Lavoie et al. 1999, Gollasch et al. 2000), but taxon and ballast tankspecific trends in plankton density during voyages remain largely unquantified. Potential sources of mortality during transport include biological factors such as (1) starvation and (2) predation; physical factors such as (3) light limitation, (4) temperature change, (5) injury during ballasting, (6) injury from turbulence during the voyage and (7) lack of settlement substrate; and chemical factors such as (8) oxygen limitation and (9) chemical toxicity (Carlton 1985, Galil \& Hülsmann 1997, Lavoie et al. 1999).

\section{Ballast-water exchange}

The growing use of ballast-water exchange to reduce invasion risk presents a new filter in the ballast invasion pathway. During open-ocean exchange, coastal ballast water is replaced with ocean water while the vessel is underway (IMO 1991, Locke et al. 1993, NRC 1996). This replacement is believed to reduce invasion risk primarily by flushing out most coastal organisms; secondarily, remaining coastal organisms may be killed by the change in conditions. However, port surveys of arriving vessels show that exchanged tanks may contain live coastal plankton (Williams et al. 1988, Hallegraeff \& Bolch 1991, Locke et al. 1993, Carlton et al. 1995, Smith et al. 1999). Exchange efficiency has been estimated directly on only 3 vessels (Rigby \& Hallegraeff 1994, Ruiz \& Hines 1997), and the effectiveness of exchange in removing live plankton remains unquantified during a commercial voyage. Further, of 2 primary methods of ballast exchange, flow-through and empty-refill (NRC 1996), only the former has been tested in vessel trials (Rigby \& Hallegraeff 1994, Ruiz \& Hines 1997).

In the present study, we compare survival of multiple taxa in 2 types of ballast tank during a transoceanic commercial voyage (ballast transport stage 2), and evaluate support for different causes of mortality during transport. We also test the ability of ballasted taxa to survive in harbor water of the recipient port at the end of the voyage (stage 3). Finally, we test the effectiveness of empty-refill ballast exchange in removing and killing coastal taxa.

\section{METHODS}

We conducted all ballast sampling and exchange experiments aboard the coal-carrier MV 'Leon' during a 3 wk trans-Atlantic voyage (see Wonham et al. 1996 for details). The 'Leon' began ballasting on 1 June 1995 in Hadera, Israel, and deballasted in Baltimore, USA, from 22 to 23 June. During the voyage, we sampled ballast water from 7 ballast tanks: a cargo hold $(\mathrm{CH})$, and 3 paired deck tanks (DT2, DT4, and DT5) (Fig. 1).

Ballast water sampling. We collected plankton with a standard $0.25 \mathrm{~m}$ diameter, $80 \mu \mathrm{m}$ mesh plankton net. On each sampling day, we collected 3 vertical plankton tows in each tank, raising the net at approximately $1 \mathrm{~m} \mathrm{~s}^{-1}$. Tows were $22 \mathrm{~m}$ deep in the cargo hold and $3 \mathrm{~m}$ (the depth of the top compartment) in the deck tanks. For all but the first day, tank openings were covered to minimize illumination during sample collection. After deballasting in Baltimore, we sampled low water and sediment at the bottom of the empty cargo hold for macrofauna. Plankton samples were examined briefly while alive, fixed in $10 \%$ formalin with Rose Bengal, and preserved in $75 \%$ ethanol before counting and identification.

One species, Oithona nana (Copepoda: Cyclopoida) was sufficiently abundant to examine for evidence of starvation. We collected them from the initial $(n=88$ 


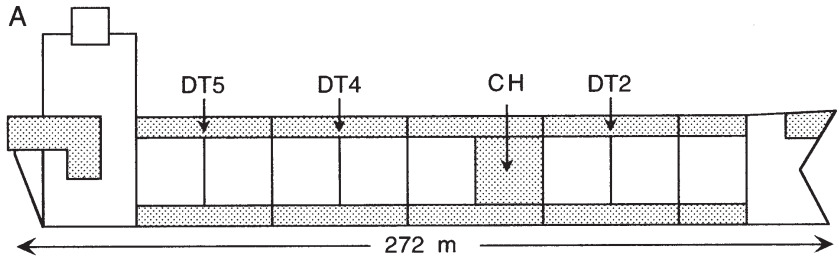

B

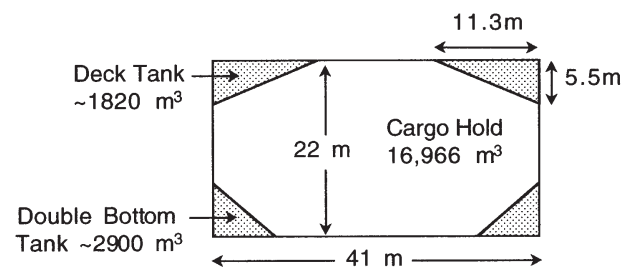

Fig. 1. Ballast tank configuration on the MV 'Leon'. (A) Vessel profile, ballast tanks shaded. Cargo hold no. $4(\mathrm{CH})$, and deck tanks (DT) 2, 4, and 5 were sampled in the present study. (B) Hull section, with dimensions and ballast capacities of cargo hold and paired deck tanks. On each side of the vessel, the deck tanks and double bottom tanks are connected by a narrow vertical sounding pipe that does not permit substantial mixing between tanks. Paired deck tanks on either side of the vessel were not connected during the voyage. Cargo hold ballast water capacity is approximately $25 \%$ of the total vessel capacity

individuals) and final ( $\mathrm{n}=20$ individuals) cargo-hold ballast-water samples and scored them for a full or empty gut.

Dissolved oxygen (DO), temperature, salinity and $\mathrm{pH}$ were measured in the cargo hold every $2 \mathrm{~h}$ throughout the voyage with a Hydrolab Datasonde 3 suspended at a depth of $10 \mathrm{~m}$. In the deck tanks, DO and temperature were measured with a hand-held YSI meter at the water surface and at $3 \mathrm{~m}$ depth. No differences were observed between the depths, so only surface values are presented.

Survivorship in Baltimore harbor. At the end of the voyage, organisms were collected from the cargo hold immediately before deballasting and were placed in $100 \mathrm{ml}$ dishes with water from the source cargo hold or from Baltimore harbor. Sample sizes were limited by the low density of living organisms to 2 dishes per treatment with 10 individuals per dish for Parvocalanus crassirostris (Copepoda: Calanoida), 3 dishes for Oithona nana, and 4 dishes for an unidentified larval spionid polychaete. The animals were maintained for $48 \mathrm{~h}$ at $25^{\circ} \mathrm{C}$, with added food (1:1 mixture of the brown alga Isochrysis galbana and the green alga Dunaliella sp. supplemented with Artemia nauplii). Animals were scored alive or dead after 24 and $48 \mathrm{~h}$.

Open ocean exchange. Three deck tanks (1 member of each pair of DT2, DT4 and DT5) were exchanged in the mid-Atlantic over $2 \mathrm{~d}$, beginning approximately 400 nautical miles west of Gibraltar $\left(24-25^{\circ} \mathrm{N}\right.$, $\left.16-25^{\circ} \mathrm{W}\right)$. The effectiveness of open-ocean exchange in removing the original water mass was estimated from the change in ballast water salinity before and after exchange, relative to simultaneously collected ocean water (salinity measured on a YSI conductivity meter model no. 32). Plankton samples were collected less than $24 \mathrm{~h}$ before and after exchange in both exchanged and unexchanged tanks. Deck tank 2 was pressed up (i.e., water added) in mid-ocean prior to exchange, so only post-exchange plankton samples were used from this tank.

In the laboratory aboard ship, we measured the survivorship of ballasted organisms in ocean water. Zooplankters were collected from the cargo hold on 14 June, and transferred to $100 \mathrm{ml}$ dishes containing filtered ballast water from either the cargo hold or the exchanged deck tanks. Ten organisms were placed in each of 5 dishes per treatment for the copepods Parvocalanus crassirostris and Oithona nana. Five organisms were placed in each of 3 dishes for Euterpina acutifrons (Copepoda: Harpacticoida) and for an unidentified juvenile spionid polychaete. Animals were maintained at room temperature and scored as alive or dead after 24 and $48 \mathrm{~h}$.

Statistical analysis. Log-transformed plankton densities were analyzed using JMP version 3 (SAS Institute). All unplanned multiple comparisons following significant ANOVA results were tested using sequential Bonferroni corrected $\alpha$-values for pairwise comparisons and a table-wide $\alpha$-value of 0.05 (Rice 1989). To evaluate trends in plankton density over time, logtransformed plankton densities were fit with a linear regression model. For the cargo hold, densities of each taxon were fit with a linear model, where the slope approximates a net mortality rate. In the deck tanks, plankton densities were fit first with a linear model; in some cases, taxa with a significant linear slope appeared better fit with an exponential decay model. Unless otherwise indicated, figures and tables show means and errors based on $\mathrm{n}=3$ tows for the cargo hold, and $\mathrm{n}=3$ tanks (with 3 tows per tank) for the deck tank values.

\section{RESULTS}

We identified at least 50 live coastal species aboard the 'Leon' (Appendix 1). This is a conservative estimate since many taxa were identified only to class or phylum. Zooplankton consisted of 44 taxa in 12 phyla, and phytoplankton consisted of 3 dinoflagellates and 2 diatoms. In addition, we collected 1 crab species $(n=6$ live juvenile portunids, Liocarcinus holstatus, carapace width 6 to $11 \mathrm{~mm}$ ) in the deballasted cargo hold at the end of the voyage. Six zooplankton taxa were collected only following open-ocean exchange (Appendix 1). 
Table 1. Mean $( \pm 1 \mathrm{SE})$ initial and final plankton densities (no. $\mathrm{m}^{-3}$ )in cargo hold and 3 unexchanged deck tanks during voyage. $\mathrm{N}=3$ replicate tows per tank. Statistic, ANOVA $F$ for plankton densities; chi-square for number of taxa. Different superscript letters indicate statistically different values determined by pairwise post-hoc comparisons

\begin{tabular}{|lccccc|}
\hline & Cargo hold & Deck tank 2 & Deck tank & Deck tank 5 & Statistic \\
\hline Initial density & $8298 \pm 1272^{\mathrm{a}, \mathrm{b}}$ & $1536 \pm 982^{\mathrm{b}, \mathrm{c}}$ & $3438 \pm 1018^{\mathrm{c}}$ & $26178 \pm 2550^{\mathrm{a}}$ & 17.38 \\
Final density & $84 \pm 8^{\mathrm{a}}$ & $24 \pm 15^{\mathrm{a}, \mathrm{b}}$ & $4.7 \pm 0.0^{\mathrm{b}, \mathrm{c}}$ & $1.6 \pm 1.9^{\mathrm{c}}$ & $<0.001$ \\
\% decrease & 99.0 & 98.5 & 99.9 & $>99.9$ & $<0.001$ \\
Initial no. taxa & 28 & 17 & 19 & 21 & 1 \\
Final no. taxa & 12 & 3 & 1 & $95.2^{\mathrm{b}}$ & 14.8 \\
\% decrease & $57.1^{\mathrm{a}}$ & $82.4^{\mathrm{b}}$ & $94.7^{\mathrm{b}}$ & $<0.01$ \\
\hline
\end{tabular}

Plankton densities decreased during the voyage by over $98 \%$ in all tanks (Table 1). Despite this high mortality, we estimate that over $1.4 \times 10^{6}$ live organisms arrived in Baltimore harbor aboard the 'Leon' (based
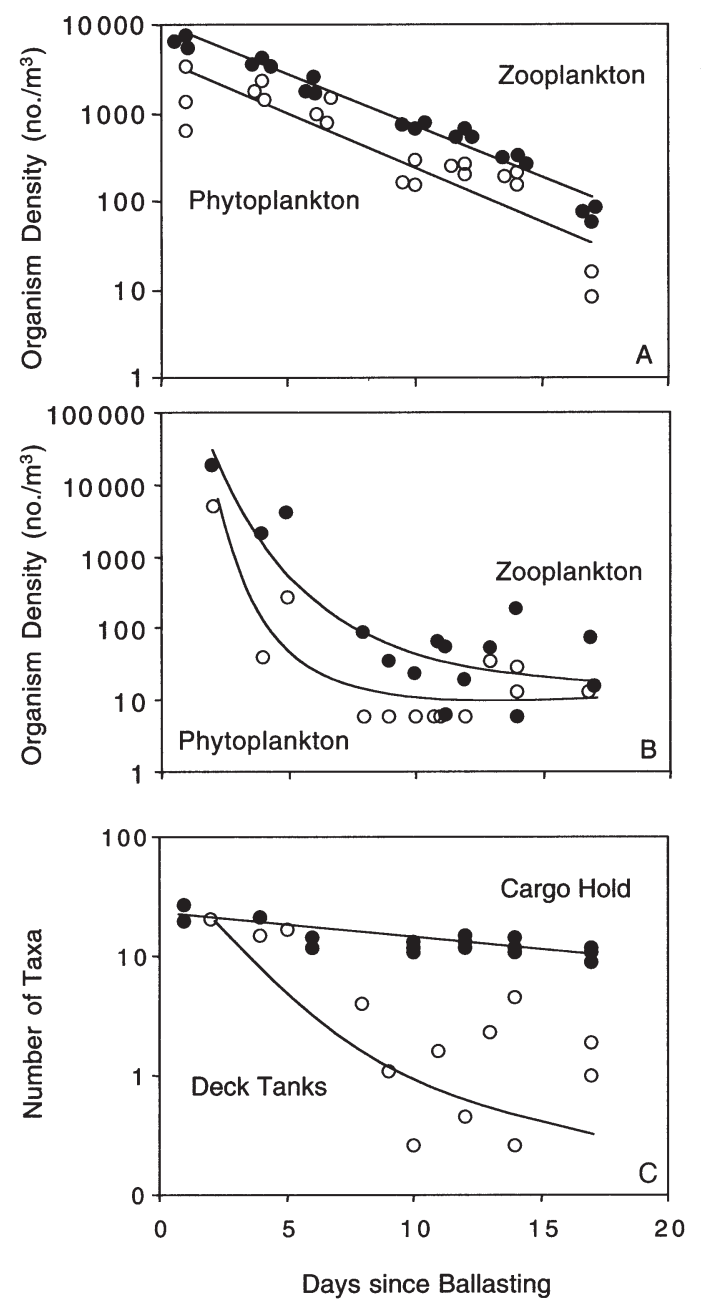

Fig. 2. Ballast-water plankton density and diversity decreased over time during voyage in (A) cargo hold and (B) deck tanks (for equations see Table 2). (C) Total taxon richness in cargo hold $(\log$ (taxon richness $\left.)=1.37-0.02 x ; \mathrm{R}^{2}=0.68, \mathrm{p}<0.001\right)$ and deck tanks $\left(\log (\right.$ taxon richness +1$\left.)=1.63 \times 10^{-0.06(x-1)}\right)$ on densities collected in an $80 \mu \mathrm{m}$ net and assuming homogeneous plankton densities). Plankton survivorship and final densities differed among taxa and between tank types.

\section{Taxon comparisons}

More taxa survived to the end of the voyage in the cargo hold than in the deck tanks (Table 1), so taxa are compared only within the cargo hold. Mortality in the deck tanks is reported under tank comparisons. In the cargo hold, zooplankton densities were significantly higher than phytoplankton densities throughout the voyage ( $t=6.39, \mathrm{p}=0.02)$, and both groups declined at the same rate (Fig. 2a, Table 2).

Within these 2 groups, 12 taxa (9 zooplankton and 3 phytoplankton) survived in the cargo hold to the end of the voyage. Mortality rate, indicated by linear regression slope, was significant for 10 of the 12 taxa (Table 2). Only poecilostomatoid copepods, which consisted primarily of Oncaea sp., and platyhelminths suffered no significant mortality during the voyage. Among these 9 zooplankton, a taxon's initial density was a significant predictor of its subsequent mortality rate (Fig. 3a). However, a taxon's final density, which is commonly measured in port-based ballast surveys, was a poor predictor of its preceeding mortality rate (Fig. 3b). All 3 dinoflagellate genera declined significantly, at indistinguishable rates (Table 2).

Copepods were the most abundant taxon in our samples, representing 63 to $99 \%$ of all zooplankton individuals throughout the voyage. The rate of copepod decline, including nauplii, juveniles, and adults, was significantly greater than that of all other larval taxa together (Gastropoda, Bivalvia, Cirripedia, Polychaeta, Platyhelminthes) (linear contrasts $F=60.30$, p $<0.0001$; Fig. 4a).

Among copepods, the cyclopoids, calanoids and harpacticoids all declined significantly during the voyage, but poecilostomatoid density remained constant (Fig. 4b, Table 2). Cyclopoids and harpacticoids de- 
Table 2. Linear regressions over time for $\log (x+1)$ transformed densities of $(A)$ the 12 taxa surviving to the end of the voyage in the cargo hold and (B) those of the 12 taxa that survived beyond initial samples in the deck tanks. Cyclopoids were represented almost exclusively by Oithona nana, calanoids by Parvocalanus crassirostris, harpacticoids by Euterpina acutifrons, and poecilostomatoids by Oncaea sp.

\begin{tabular}{|c|c|c|c|c|c|c|}
\hline Taxa & $\mathrm{R}^{2}$ & Intercept & $\mathrm{SE}$ & Slope & SE & $\mathrm{p}$ \\
\hline \multicolumn{7}{|l|}{ (A) Cargo hold } \\
\hline Zooplankton & 0.96 & 4.00 & 0.05 & -0.12 & 0.00 & $<0.001$ \\
\hline Copepoda & 0.94 & 4.02 & 0.08 & -0.13 & 0.01 & $<0.001$ \\
\hline Cyclopoida & 0.96 & 3.93 & 0.07 & -0.14 & 0.01 & $<0.001$ \\
\hline Calanoida & 0.86 & 3.21 & 0.10 & -0.10 & 0.01 & $<0.001$ \\
\hline Harpacticoida & 0.94 & 2.96 & 0.08 & -0.13 & 0.01 & $<0.001$ \\
\hline Poecilostomatoida & 0.09 & 1.50 & 0.18 & -0.02 & 0.02 & 0.186 \\
\hline Cirripedia & 0.55 & 0.79 & 0.12 & -0.05 & 0.01 & $<0.001$ \\
\hline Bivalvia & 0.50 & 1.69 & 0.20 & -0.04 & 0.01 & $<0.001$ \\
\hline Gastropoda & 0.59 & 0.89 & 0.11 & -0.05 & 0.01 & $<0.001$ \\
\hline Polychaeta & 0.34 & 1.35 & 0.12 & -0.04 & 0.01 & 0.006 \\
\hline Platyhelminthes & 0.13 & 0.66 & 0.12 & -0.02 & 0.01 & 0.102 \\
\hline Phytoplankton & 0.79 & 3.60 & 0.15 & -0.12 & 0.01 & $<0.001$ \\
\hline Ceratocorys sp. & 0.82 & 3.16 & 0.19 & -0.17 & 0.02 & $<0.001$ \\
\hline Protoperidinium sp. & 0.77 & 3.34 & 0.14 & -0.11 & 0.01 & $<0.001$ \\
\hline Ceratium sp. & 0.78 & 2.28 & 0.12 & -0.10 & 0.01 & $<0.001$ \\
\hline \multicolumn{7}{|l|}{ (B) Deck tanks } \\
\hline Zooplankton & 0.55 & 3.71 & 0.62 & -0.22 & 0.05 & 0.001 \\
\hline Cyclopoida & 0.64 & 2.99 & 0.49 & -0.21 & 0.04 & $<0.001$ \\
\hline Calanoida & 0.72 & 3.13 & 0.50 & -0.23 & 0.05 & $<0.001$ \\
\hline Harpacticoida & 0.56 & 3.38 & 0.61 & -0.22 & 0.05 & $<0.001$ \\
\hline Poecilostomatoida & 0.75 & 1.43 & 0.18 & -0.10 & 0.12 & $<0.001$ \\
\hline Bivalvia & 0.63 & 1.73 & 0.34 & -0.13 & 0.03 & $<0.001$ \\
\hline Polychaeta & 0.72 & 1.69 & 0.28 & -0.13 & 0.03 & $<0.001$ \\
\hline Phytoplankton & 0.64 & 2.10 & 0.55 & -0.14 & 0.05 & 0.011 \\
\hline Ceratium sp. & 0.27 & 1.05 & 0.33 & -0.06 & 0.03 & 0.046 \\
\hline
\end{tabular}

clined significantly faster than calanoids or poecilostomatoids. Poecilostomatoids declined significantly more slowly than all other orders (pairwise linear contrasts $\mathrm{p}<0.05$ in all cases), with a slope indistinguishable from zero (Fig. 4b, Table 2). No taxa or stages showed a net increase in density during the voyage.

Significantly more cyclopoid copepods, Oithona nana, had full guts at the beginning of the voyage $(41 / 88)$ than at the end of the voyage $(4 / 20)$ in the cargo hold (Fisher's Exact Test, $\mathrm{p}=0.043$ ).

\section{Tank comparisons}

Plankton density and diversity varied among tanks. Initial plankton density was significantly higher in Deck Tank 5, which was ballasted last, than in Deck Tanks 2 and 4 (Table 1). Initial cargo hold density was intermediate. Final plankton density was significantly higher in the cargo hold than in the deck tanks (Table 1).

Initial taxon richness tended to be higher in the cargo hold than in the deck tanks (Table 1). This difference appears to be largely accounted for by the higher total tow volume of samples collected in the cargo hold (Fig. 5). In the deck tanks the cumulative total number of taxa collected in 3 tows of $0.15 \mathrm{~m}^{3}$ each is approximately the same as the number of taxa collected in the first of the cargo hold tows $\left(1.1 \mathrm{~m}^{3}\right)$ (Fig. 5). Final taxon richness was significantly higher in the cargo hold than in the deck tanks. This difference appears greater than what might be expected simply from differences in sample volume (Fig. 5), and reflects the higher mortality suffered by taxa in the deck tanks during the voyage.

Twelve phytoplankton and zooplankton taxa were collected in the cargo hold at the end of voyage; of these, only 3 were collected in the final deck tank samples: Euterpina acutifrons, Oncaea sp., and the dinoflagellate Ceratium sp. The final densities of these 3 taxa did not vary significantly between tank types. The higher plankton density in the cargo hold at the end of the voyage was due therefore to the significantly higher number of taxa (Fig. 5), rather than to higher densities of these 3 taxa.

Total zooplankton proportional mortality was significantly greater in the deck tanks than in the cargo hold (linear contrasts $F=6.62, \mathrm{p}=0.015$ ) (Table 2). Slopes for phytoplankton were indistinguishable between tank types (Table 2). Total taxon richness also declined 

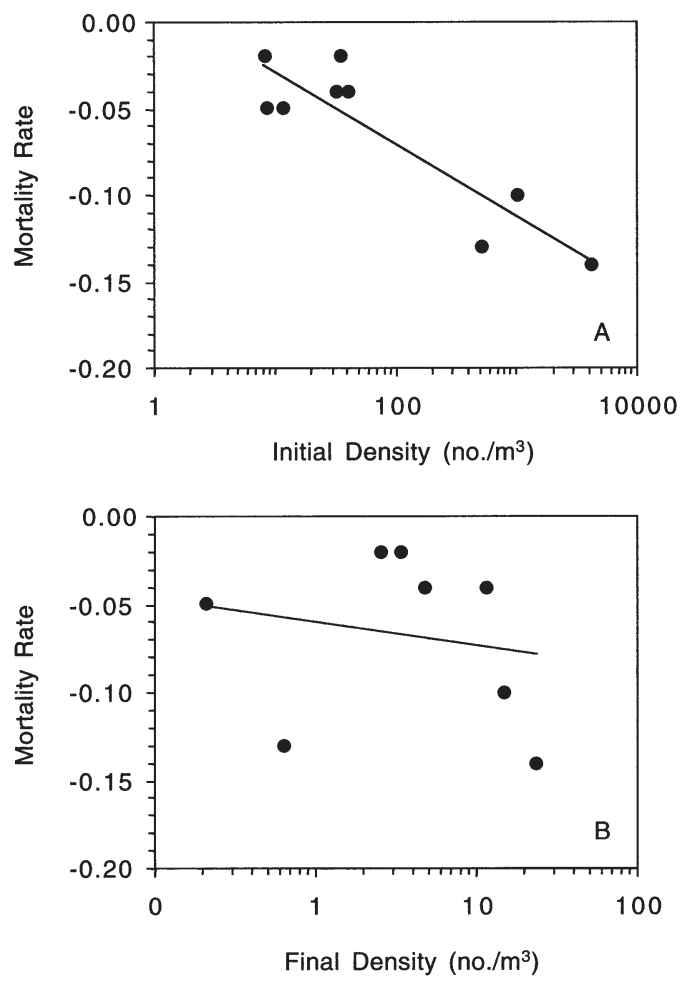

Fig. 3. Mortality rate of 9 zooplankton taxa vs (A) Initial plankton density $\left(y=0.013-0.042 x, R^{2}=0.80, p=0.001\right)$ and (B) Final plankton density $\left(y=-0.060-0.014 x, R^{2}=0.05, p=\right.$ 0.556). Mortality rate is slope of linear regression of taxon density over time (Table 2)

faster in the deck tanks than in the cargo hold (linear contrasts $F=9.16, \mathrm{p}=0.001$ ). However, both plankton densities and taxon richness in the deck tanks appeared to be fit better with an exponential model than with a linear model, suggesting that proportional loss of organisms and taxa in these tanks decreased over time (Fig. 2b,c). At the taxon level, log-densities of most taxa appeared better fit with an exponential model (Table 3) than with a linear model (Table 2).

\section{Physical conditions}

Mean daily dissolved oxygen level $( \pm 1$ SD) was more than twice as high in the cargo hold $\left(8.0 \pm 0.2 \mathrm{mg} \mathrm{l}^{-1}\right)$ than in Deck Tanks 2,4 and $5(3.1 \pm 0.3,3.2 \pm 0.6,3.3 \pm$ $1.0 \mathrm{mg} \mathrm{l}^{-1}$, respectively) (ANOVA, $\mathrm{n}=4$ tanks, $F=5.82$, $\mathrm{p}=0.005)$. Mean daily water temperature in all tanks varied over only $2^{\circ} \mathrm{C}$, from $23.8( \pm 1.2)^{\circ} \mathrm{C}$ in DT2 to 25.7 $( \pm 1.2)^{\circ} \mathrm{C}$ in DT5. Mean daily salinity remained constant in all tanks, over a range from $36.9( \pm 0.1)$ ppt in DT5 to $38.7( \pm 0.1)$ ppt in the cargo hold. Mean daily $\mathrm{pH}$ was $8.12( \pm 0.02)$ in the cargo hold, and was not measured in the deck tanks.
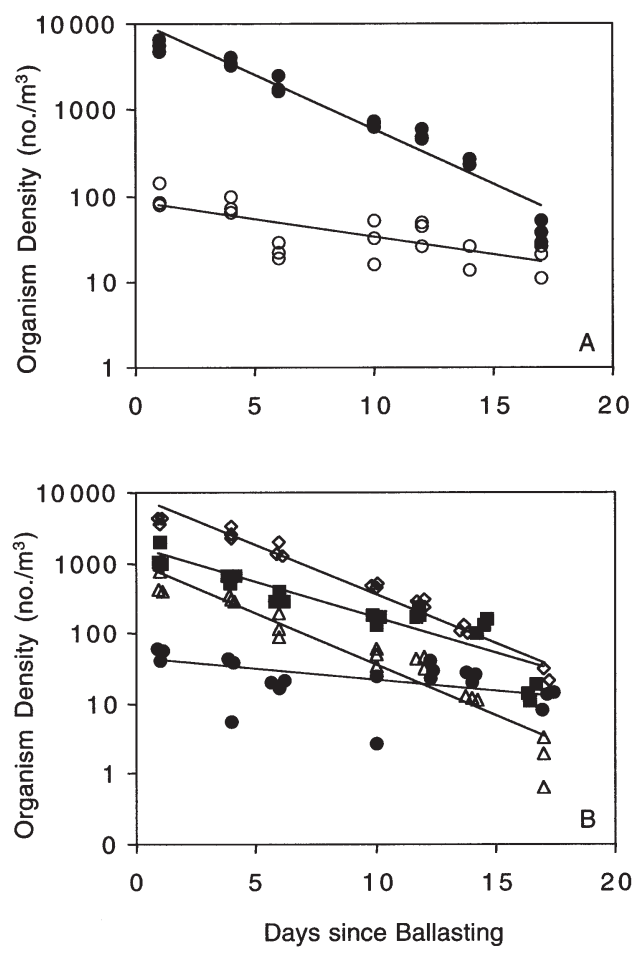

Fig. 4. Taxon-specific changes in density over time during the ballast voyage. (A) Copepods (•) declined significantly faster than larvae (O). Copepods include the 3 orders Cyclopoida, Calanoida, and Harpacticoida. Larvae include flatworms, polychaetes, barnacles, bivalves, and gastropods. (B) Among copepods, cyclopoids $(\diamond)$ and harpacticoids $(\Delta)$ declined sig-

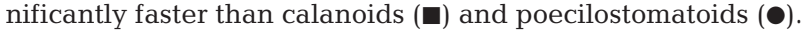
Only poecilostomatoids showed no significant change in density over time. Regression equations, see Table 2

\section{Survivorship in Baltimore harbor water}

Organisms transferred to Baltimore harbor water at the end of the voyage suffered $100 \%$ mortality within $24 \mathrm{~h}$. In contrast, organisms transferred to ballast water survived for more than $48 \mathrm{~h}$. Survivorship at $48 \mathrm{~h}$ was significantly greater for the spionid (mean 97.9\%; $95 \%$ $\mathrm{CI}=82.7-98.1 \% ; \mathrm{n}=4$ dishes), than for the 2 copepods Parvocalanus crassirostris (70.0 and $80.0 \% ; \mathrm{n}=2$ dishes) and Oithona nana (mean 57.8\%; CI = 41.6 $73.2 \% ; \mathrm{n}=3$ dishes) (ANOVA $F=125, \mathrm{p}<0.0001$; NB small sample sizes).

\section{Ballast exchange}

Mean salinity in the exchanged tanks decreased significantly following exchange (Student's $t$-test $\mathrm{p} \leq$ 0.001 in each tank) (Table 4). Bootstrapped estimates of mean exchange effectiveness using all 3 measures 


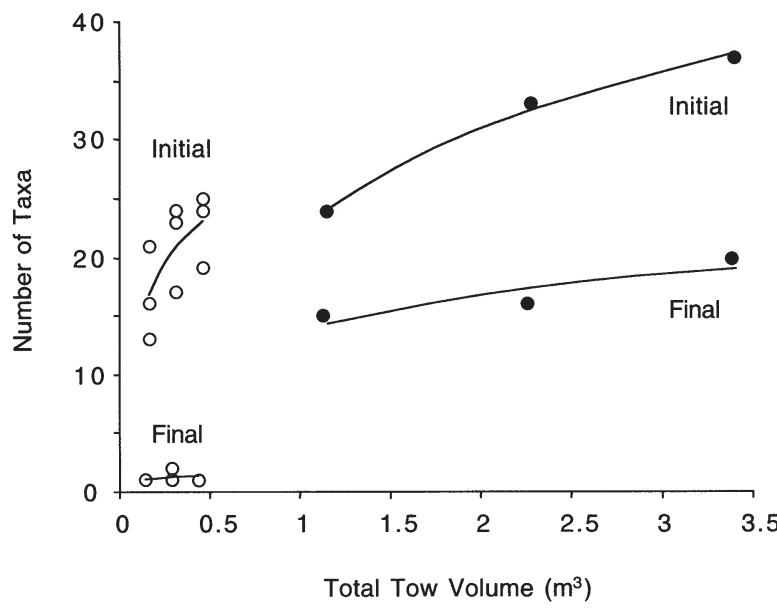

Fig. 5. Cumulative total number of taxa collected in 3 subsequent plankton tows in the deck tanks $(0)$ and in the cargo hold ( ) on initial and final sampling times. Tows from all 3 deck tanks are plotted together for initial samples; tows from 2 deck tanks plotted together for final samples. The higher initial diversity in the cargo hold appears largely due to the greater sample volume $\left(1.1 \mathrm{~m}^{3}\right.$ per tow in cargo hold vs $0.15 \mathrm{~m}^{3}$ in deck tanks), but the higher final diversity appears to be independent of sample volume

Table 3. Exponential decay parameters for densities of 6 taxa in the deck tanks over time. Exponential model, log(density + 1) $=\beta_{0}{ }^{\left(\beta_{1}(x-1)\right)}$ with approximate standard errors

\begin{tabular}{|lcccc|}
\hline Taxa & $\beta_{0}$ & SE & $\beta_{1}$ & SE \\
\hline Zooplankton & 5.31 & 0.78 & -0.17 & 0.03 \\
Cyclopoida & 4.84 & 0.70 & -0.25 & 0.04 \\
Calanoida & 4.77 & 0.59 & -0.26 & 0.04 \\
Harpacticoida & 5.24 & 1.83 & -0.21 & 0.04 \\
Bivalvia & 3.43 & 0.34 & -0.36 & 0.04 \\
Polychaeta & 2.79 & 0.28 & -0.30 & 0.04 \\
Phytoplankton & 5.30 & 0.90 & -0.40 & 0.08 \\
Ceratium sp. & 2.77 & 0.62 & -0.37 & 0.10 \\
\hline
\end{tabular}

of salinity from each tank ranged from 93.3\% in Deck Tank 5 to $100 \%$ in Deck Tank 4 (Table 4). Water temperature and dissolved oxygen did not differ significantly between exchanged and unexchanged tanks, before or after exchange.

The mean density of organisms increased significantly following exchange and remained significantly higher at the end of the voyage (Repeated measures ANOVA $F=32$, df $=1$, p < 0.0001) (Fig. 6). The number of taxa also increased significantly following exchange $\left(\chi^{2}=4.27, \mathrm{p}=\right.$ 0.039) (Fig. 6).

Some coastal taxa increased in density after exchange while others decreased. Since most taxa could not be identified to species level, it is unclear whether the organisms collected after exchange were members of the same or different species. Three coastal taxa decreased following exchange in 1 or more tanks: cyprids, gastropods and Euterpina acutifrons (Table 5). Mean estimates of exchange efficacy vary by taxon from $100 \%$ (cyprids in both tanks, gastropods in DT5, and E. acutifrons in DT4) to $80 \%$ ( $E$. acutifrons in DT5) (Table 5). However, the variance in plankton density was so high relative to the mean densities that exchange efficacy is impossible to distinguish from $0 \%$ in most cases (Table 5). The density of gastropods decreased following exchange in DT5, but increased in DT4. Six new ocean taxa were collected following exchange (Appendix 1).

Ocean water was not lethal to coastal organisms. Zooplankton collected from the cargo hold at the time of exchange showed no significant difference in survivorship between ocean water and ballast tank water after $48 \mathrm{~h}$ (Fig. 6). Survivorship was significantly higher for the spionid polychaete and significantly lower for Euterpina acutifrons and Oithona nana than for Parvocalanus crassirostris (ANOVA $F=29.9$, p < 0.0001) (Fig. 7).

\section{DISCUSSION}

The density and richness of potential invaders decreased significantly during ballast-water transport. The plankton assemblage surviving to the end of the voyage represented less than $2 \%$ of the density and fewer than $50 \%$ of the taxa initially ballasted (Table 1 , Fig. 2). These levels of mortality are comparable to those reported for select taxa over similar length voyages (Carlton et al. 1982, Rigby \& Hallegraeff 1994, Gollasch et al. 2000, Smith et al. in press). Final total plankton density was approximately 84 organisms $\mathrm{m}^{-3}$ in the cargo hold, somewhat lower than maximum densities reported in ballast surveys for organisms in this size range (Chu et al. 1997, Ruiz \& Hines 1997,

Table 4 . Salinity of ballast water (mean $\pm 1 \mathrm{SD}$ ) before and after exchange, and salinity of ocean water. In all tanks, salinity after exchange was statistically indistinguishable from ocean water salinity. Mean efficacy of open ocean exchange (bootstrap mean \pm $1 \mathrm{SE}$ ) and range of minimum and maximum possible efficacies calculated from salinity measurements

\begin{tabular}{|lccc|}
\hline Salinity & Deck Tank 2 & Deck Tank 4 & Deck Tank 5 \\
\hline Before exchange & $36.87 \pm 0.09$ & $37.00 \pm 0.07$ & $37.22 \pm 0.09$ \\
After exchange & $34.61 \pm 0.16$ & $34.72 \pm 0.09$ & $34.94 \pm 0.10$ \\
Ocean water & $34.84 \pm 0.19$ & $34.84 \pm 0.19$ & $34.84 \pm 0.19$ \\
Efficacy (\%) & $99.5 \pm 0.06$ & $100 \pm 0.00$ & $93.3 \pm 0.30$ \\
Range & $95-100$ & 100 & $75-100$ \\
\hline
\end{tabular}




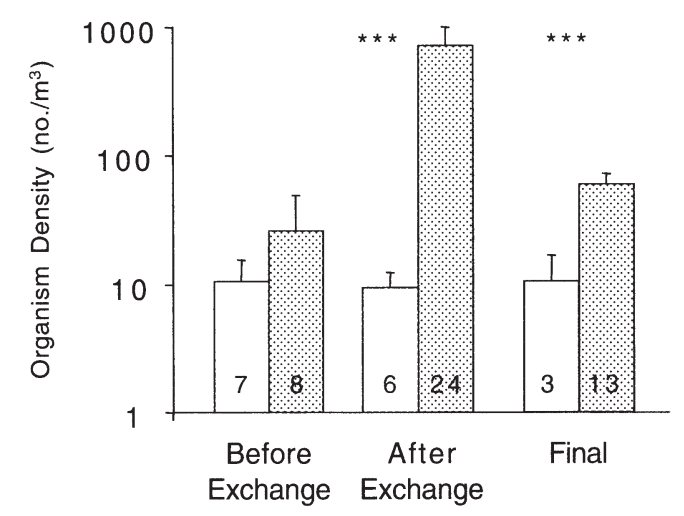

Fig. 6. Mean density of organisms remained constant in unexchanged tanks (light bars) following exchange, but increased significantly in exchanged tanks (dark bars) and remained significantly higher in final samples at end of voyage. Bars, mean of $\mathrm{n}=9$ plankton tows $(\mathrm{n}=6$ for Before Exchange); with error bars = 1 SE. Numbers on bars indicate number of taxa. ${ }^{* * *}$ Significant difference between exchanged and unexchanged tanks determined by post-hoc $t$-tests at $\mathrm{p}<0.0001$

Lavoie et al. 1999, Smith et al. 1999, Levings et al. 1999). Mortality rates were variable among taxa during transport, but uniformly high upon transfer to Baltimore harbor water.

\section{Predicting invasion success}

A successful invasion requires both an adequate density (e.g. Williamson 1996) and an adequate quality or condition of organisms (Pechenik 2000, Ruiz et al. 2000). Most studies of ballasted organisms, including ours, have focused on the density of taxa. The condition of organisms is more difficult to ascertain, but it seems likely that those taxa suffering high mortality during a voyage may be in poor condition by the end. Mortality rates may thus provide a proxy measure of a species' condition, and therefore of its ability to invade. Interestingly, these 2 potential predictors of invasion

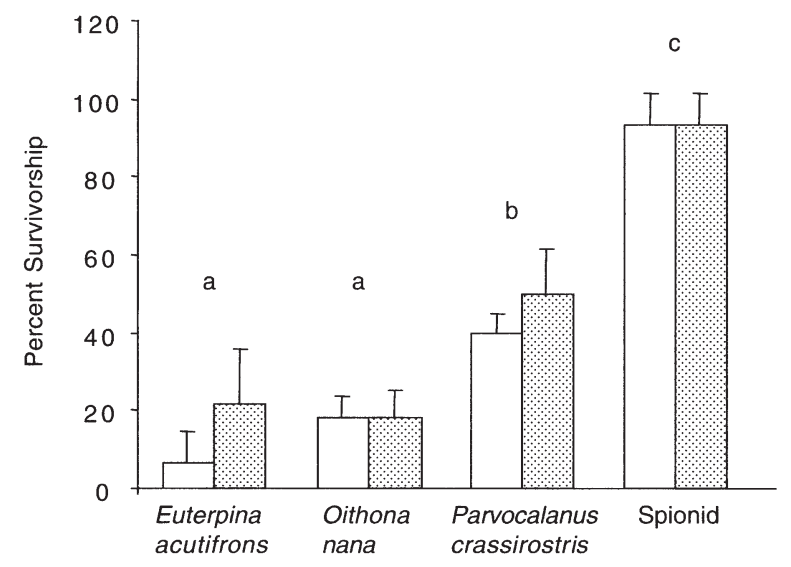

Fig. 7. Coastal ballast taxa survived equally well in the laboratory in ballast-tank (light bars) and open-ocean (dark bars) water after $48 \mathrm{~h}$. Mean survival $( \pm 1 \mathrm{SE}$ ) for $\mathrm{n}=5$ dishes with 10 individuals each (P. crassirostris and $O$. nana) and $\mathrm{n}=3$ dishes with 5 individuals each (E. acutifrons and spionid). Different letters indicate statistically different survivorship for different taxa from pairwise post-hoc comparisons (ANOVA $F=29.9, \mathrm{p}<0.001)$

success, high final density and low mortality rate, were not correlated with each other across taxa (Fig. 4b). In particular, copepods (excluding poecilostomatoids) were significantly more abundant, but suffered significantly higher mortality than larval taxa.

Copepods in general exhibit a striking disparity between delivery frequency and invasion success. They are typically the most abundant and frequently collected organisms in ballast water (Carlton 1985, Locke et al. 1993, Carlton \& Geller 1993, Chu et al. 1997, Smith et al. 1999, Gollasch et al. 2000, present study), but, notwithstanding the dramatic effects of some of these invasions (e.g., Cordell \& Morrison 1996, Orsi \& Ohtsuka 1999), they represent fewer than $2 \%$ of introduced holo- and meroplanktonic species reported in North American and Australian coastal waters (Pollard \& Hutchings 1990, Ruiz et al. 2000). This disparity between transport frequency and invasion frequency may be explained by poor condition, and asso-

Table 5. Mean density (no. $\mathrm{m}^{-3} \pm 1 \mathrm{SE}$ ) before and after open-ocean exchange, for the 3 taxa that decreased in at least 1 tank following exchange: Euterpina acutifrons (Copepoda: Harpacticoida), Cirripedia (cyprid larvae) and Gastropoda (veliger larvae). Deck tank 4, exchanged 13 June; Deck tank 5, exchanged 14 June. Note the striking difference between tanks in post-exchange gastropod densities. The high variance associated with density measurements before exchange makes efficacy estimates only approximate. na: efficacy could not be calculated

\begin{tabular}{|c|c|c|c|c|c|c|}
\hline & \multicolumn{2}{|c|}{ Euterpina acutifrons } & \multicolumn{2}{|c|}{ Cirripedia } & \multicolumn{2}{|c|}{ Gastropoda } \\
\hline & Deck Tank 4 & Deck Tank 5 & Deck Tank 4 & Deck Tank 5 & Deck Tank 4 & Deck Tank 5 \\
\hline Before exchange & $0.38 \pm 0.46$ & $0.75 \pm 0.92$ & $0.38 \pm 0.46$ & $0.38 \pm 0.46$ & $0.00 \pm 0.00$ & $0.38 \pm 0.46$ \\
\hline After exchange & $0.00 \pm 0.00$ & $0.38 \pm 0.46$ & $0.00 \pm 0.00$ & $0.00 \pm 0.00$ & $7.56 \pm 0.40$ & $0.00 \pm 0.00$ \\
\hline Efficacy (\%) & $100 \pm 0.00$ & $80 \pm 0.29$ & $100 \pm 0.00$ & $100 \pm 0.00$ & na & $100 \pm 0.00$ \\
\hline
\end{tabular}


ciated high mortality rates, of copepods on ballast voyages (Fig. 3a). Alternatively, frequent and dense ballast transport may have led to numerous successful invasions in the past that go unrecognized today, reflecting a lack of appropriate sampling (Ruiz et al. 2000). Overall, however, it is likely that the condition of arriving propagules can substantially modify the relationship between delivery and invasion success.

The outcome of ballast-water transport is also influenced strongly by survival at the recipient port. In our study, none of the taxa tested survived transfer to local waters. This high mortality presumably resulted from the considerable difference in salinity (approximately $35 \mathrm{ppt}$ ). While low salinity of Baltimore harbor (approximately 5 to $10 \mathrm{ppt}$ ) may consistently reduce the risk of invasion by organisms from high salinity ports (Smith et al. 1999), this is a highly case-specific filter, and the environmental mismatch will be less severe for many other pairs of coastal ports. Thus, the relative importance of changes in plankton quantity and quality in predicting invasion success will vary greatly among ports.

\section{Causes of mortality}

Carlton (1985) suggested that in the dark ballast tanks, phytoplankton production stops and herbivorous zooplankton are food limited, whereas bacterial grazers, detritivores, scavengers, non-feeding larvae, or larvae with food reserves may survive better. We found that significantly more individuals of the cyclopoid copepod Oithona nana had empty guts at the end of the voyage than at the beginning, suggesting that this species, at least, was food-limited. We evaluate support for several additional predictions suggested by the food-limitation hypothesis.

Mortality would be higher for holoplanktonic filter feeders and predators than for meroplanktonic larvae with food reserves

We found that copepods (cyclopoids, harpacticoids, and calanoids together), the dominant holoplankton, showed significantly higher mortality than meroplanktonic larval taxa (gastropods, bivalves, barnacles, polychaetes, and flatworms). This pattern differs from that reported for short intracoastal voyages, where copepods survived better than larvae and starvation may not have become important (Lavoie et al. 1999). We would also expect non-feeding larvae to survive better than feeding larvae, but this pattern would be confounded by the shorter duration of many non-feeding larval stages.
Mortality would be higher for herbivorous than for detritivorous and microbial grazer holoplankton

Chu et al. (1997) found that cyclopoid and calanoid, but not harpacticoid copepod densities, were lower in ships with older ballast water. They suggested that harpacticoids, grazing on bacterial production, survived better than the herbivorous copepods. In contrast, we found that the densities of cyclopoids (primarily the omnivorous mid-water feeder Oithona nana) and harpacticoids (primarily the herbivorous Euterpina acutifrons) decreased fastest. Calanoids (primarily the suspension feeding Parvocalanus crassirostris) decreased at an intermediate rate. Poecilostomatoids (primarily the omnivorous Oncaea sp.), showed no significant decrease in density during the voyage. High survival of Oncaea sp., which has a broad diet that includes scavenging midwater detritus (e.g., Steinberg et al. 1994, Hwang \& Turner 1995) and may therefore be less dependent on phytoplankton for food, is consistent with the hypothesis of lightlimitation and starvation. The surprisingly high mortality of harpacticoids may reflect the particular diet of the dominant harpacticoid E. acutifrons, which appears to be primarily an algal grazer (Sautour \& Castel 1993).

\section{Zooplankton mortality would lag behind phytoplankton mortality}

Our data do not indicate any lag in the zooplankton decline relative to the phytoplankton, but we measured only the comparatively large phytoplankton fraction filtered by an $80 \mu \mathrm{m}$ net. Smaller mesh nets would provide a more accurate picture of the overall phytoplankton community including smaller dinoflagellates and diatoms (e.g., Hallegraeff \& Bolch 1991, Subba Rao et al. 1994, Galil \& Hülsmann 1997).

\section{Zooplankton mortality would be density-dependent}

Zooplankton competing for limited food could exhibit density-dependent mortality. Among zooplankton taxa, we found that higher mortality rates were associated with higher initial densities. In addition, overall zooplankton mortality rate in the deck tanks tended to decrease as zooplankton densities decreased over time. However, this latter pattern probably does not represent a density-dependent response, but rather reflects the rapid, early loss of more sensitive taxa followed by the persistence of more robust taxa. 
Mortality rates would be higher for photosynthetic than for heterotrophic phytoplankton

We found no significant difference in mortality rate between the heterotrophic dinoflagellate Protoperidinium sp. and the autotrophic dinoflagellate Ceratium sp.

In addition to these bottom-up trophic interactions, physical conditions may have contributed to plankton mortality. Dissolved-oxygen levels and plankton survivorship were lower in the deck tanks than in the cargo hold, suggesting that oxygen limitation in the deck tanks may have reduced plankton survivorship. However, 2 additional factors may explain the higher mortality rates in the deck tanks. The cargo hold sampling depth was 23 $\mathrm{m}$, but the deck tank upper compartments were only $3 \mathrm{~m}$ deep. If plankton tended to sink at the same rate to the bottom of both tank types, organisms would disappear sooner from the deck tank samples than from the cargo hold samples. Further, since deck tanks are higher than the cargo hold above the ship's center of gravity, they may experience heavier water movement during rough weather, a phenomenon that has been correlated with high mortality during other voyages (Carlton et al. 1982). Mortality has also been associated with large changes in ballast water temperature (Carlton et al. 1982, Gollasch et al. 2000), but on this voyage as on several others (Carlton et al. 1982, Rigby \& Hallegraeff 1994, Gollasch et al. 2000), mortality was high despite relatively constant temperatures.

Predation by macrofauna is unlikely to have contributed to mortality on this voyage. We collected only 2 larval fish during the voyage, and found no fish and only 6 small portunid crabs in the deballasted cargo hold at the end of the voyage. Other factors such as physical damage during ballasting, or the possible release of chemicals such as zinc (from anti-corrosion anodes in the deck tanks) (Jelmert \& van Leeuwen 2000) or other compounds were not evaluated.

\section{Effectiveness of open-ocean exchange}

Ballast-water exchange represents a new and fundamental alteration to an invasion pathway that has been in operation for decades. We found that empty-refill exchange replaced 96 to $100 \%$ of coastal water, a level consistent with salinity-based measures of exchange on 2 other vessels (Ruiz \& Hines 1997). Exchange also replaced an estimated 80 to $100 \%$ of live coastal organisms, although the high variability in pre-exchange plankton densities makes these estimates only approximate. However, they are consistent with estimates based on dye concentrations and dead plankton densities on one other vessel (Rigby \& Hallegraeff 1994).
Total plankton density and diversity increased following exchange. Since most taxa could not be identified to species, we do not know whether the postexchange individuals in a given taxon were coastal individuals retained during exchange, new oceanic individuals of the same species, or new oceanic individuals of a new species in the same taxon.

Ocean water was not lethal to 4 originally ballasted coastal taxa. Unlike many coastal ports, however, the water in Hadera harbor is hypersaline (36 to $39 \mathrm{ppt}$ ), and close to open ocean salinities ( 35 ppt). Mortality from the osmotic stress of salinity change would be more likely to affect coastal organisms from brackish or fresh water (Smith et al. 1999). Our sampling methods did not allow us to evaluate the effectiveness of exchange in removing smaller size fraction and encysted phytoplankton or bacteria, which are known to be transported in ballast water (Hallegraeff \& Bolch 1991, Hallegraeff 1998, Subba Rao et al. 1994, Galil \& Hülsmann 1997).

The stochastic nature of the invasion process makes it difficult to predict the identity and timing of an individual invasion event (Carlton 1996). In the case of ballast-water transport, the problem is exacerbated by the difficulty of identifying many larval organisms to species (Carlton 1996, Smith et al. 1999). This stochasticity does not mean, however, that ballast transport of potential invaders does not exhibit predictable patterns or cannot effectively be reduced. Clearly, ballast transport selectively filters taxon density and diversity during a voyage. Interestingly, 2 potential predictors of invasion success, mortality during transport (which may, indicate body condition), and final organism density, were not correlated across taxa. Although the specific causes of mortality remain speculative, trends in survivorship point to the roles of light, food, and oxygen limitation on this voyage. Open-ocean exchange represents an additional selective filter in the ballast invasion pathway, that reduces but does not eliminate coastal taxa.

Acknowledgements. This research was supported by the U.S. Fish and Wildlife Service and the Compton Foundation. J. Carlton, D. Smith, A. Hines and C. Czarnecki provided logistic support and thoughtful discussion throughout the project. D. Friedmann cheerfully provided invaluable field and linguistic assistance during the voyage, and S. Godwin, D. Smith, L. McCann and P. Fofonoff provided field and laboratory assistance in Baltimore. D. Correll loaned equipment for salinity analysis. We are grateful for the taxonomic expertise of F. Ferrari (copepods), S. Godwin and A. Williams (decapods). For statistical advice, we are indebted to G. Gilchrist and E. Holmes. We thank El-Yam Ships Ltd., National Coal Supply Corporation Ltd., John S. Connor Shipping Agency, and Consolidation Coal Dock for their cooperation and assistance. This study would not have been possible without the enthusiastic hospitality and collaboration of Captain Reujder and the officers and crew of the MV 'Leon'. 
Appendix 1. Taxa collected during the 16 d voyage from Israel to Baltimore, USA. Plankton collected in C, cargo hold; D, unexchanged or pre-exchange deck tanks; E, exchanged deck tanks following exchange

\begin{tabular}{|c|c|c|c|}
\hline Taxa & Collection & Taxa & Collection \\
\hline Zooplankton & & Harpacticoida (continued) & \\
\hline Tintinnida & $\mathrm{E}$ & Canuellidae & $\mathrm{C}, \mathrm{D}$ \\
\hline Foraminifera & $\mathrm{C}$ & Other cyclopoids & $\mathrm{C}, \mathrm{D}$ \\
\hline Cnidaria & & Poecilostomatoida & \\
\hline Hydromedusa & $\mathrm{C}, \mathrm{D}$ & Corycaeus sp. & $\mathrm{C}, \mathrm{D}, \mathrm{E}$ \\
\hline Siphonophora & $\mathrm{C}$ & Oncaea sp. & $\mathrm{C}, \mathrm{D}, \mathrm{E}$ \\
\hline Ctenophora & $\mathrm{C}$ & Other poecilostomatoids & $\mathrm{C}, \mathrm{D}$ \\
\hline Platyhelminthes & $\mathrm{C}, \mathrm{D}$ & Copepod nauplii & $\mathrm{C}, \mathrm{D}, \mathrm{E}$ \\
\hline Mollusca & & Copepoda, unidentified & $\mathrm{C}, \mathrm{D}, \mathrm{E}$ \\
\hline Bivalvia & $\mathrm{C}, \mathrm{D}, \mathrm{E}$ & Cladocera & \\
\hline Gastropoda & $\mathrm{C}, \mathrm{D}, \mathrm{E}$ & Evadne spinifer & $\mathrm{E}$ \\
\hline Other molluscs & $\mathrm{D}$ & Cirripedia & \\
\hline Polychaeta & & Cyprid larvae & $\mathrm{D}$ \\
\hline Spionidae & $\mathrm{C}, \mathrm{D}$ & Naupliar larvae & $\mathrm{C}, \mathrm{D}$ \\
\hline Chaetognatha & $\mathrm{C}, \mathrm{D}, \mathrm{E}$ & Decapoda & \\
\hline Nematoda & $\mathrm{D}$ & Anomura (larvae) & $\mathrm{C}$ \\
\hline Crustacea & & Brachyura (zoeae) & $\mathrm{C}, \mathrm{D}$ \\
\hline Copepoda & & Caridea & $\mathrm{C}, \mathrm{D}$ \\
\hline Calanoida & & Euphausiacea & $\mathrm{C}, \mathrm{D}$ \\
\hline Centropages sp. & $\mathrm{C}, \mathrm{D}$ & Mysidacea & $\mathrm{C}, \mathrm{D}$ \\
\hline Clausocalanus sp. & $\mathrm{C}, \mathrm{D}$ & Sergestidae & $\mathrm{C}, \mathrm{E}$ \\
\hline Labidocera sp. & $\mathrm{D}$ & Shrimp (unidentified) & $\mathrm{C}$ \\
\hline Paracalanus sp. & $\mathrm{C}, \mathrm{D}, \mathrm{E}$ & Gammaridea & $\mathrm{C}$ \\
\hline Parvocalanus crassirostris & $\mathrm{C}, \mathrm{D}, \mathrm{E}$ & Isopoda & $\mathrm{C}$ \\
\hline Pseudocyclopia sp. & $\mathrm{D}$ & Zoeae (unidentified) & $\mathrm{E}$ \\
\hline Temora sp. & $\mathrm{C}, \mathrm{D}$ & Bryozoa & $\mathrm{C}$ \\
\hline Acartia sp. & E & Pisces & $\mathrm{C}, \mathrm{D}$ \\
\hline Calanoids, unidentified & $\mathrm{C}, \mathrm{D}, \mathrm{E}$ & Eggs (unidentified) & $\mathrm{D}, \mathrm{E}$ \\
\hline \multicolumn{4}{|l|}{ Cyclopoida } \\
\hline Oithona nana & $\mathrm{C}, \mathrm{D}, \mathrm{E}$ & Phytoplankton & \\
\hline Oithona sp. A & $\mathrm{D}$ & Dinoflagellida & \\
\hline Oithona sp. B & $\mathrm{E}$ & Ceratium sp. & $\mathrm{C}, \mathrm{D}, \mathrm{E}$ \\
\hline ?Hemicyclops sp. & $\mathrm{D}$ & Ceratocorys sp. & $\mathrm{C}, \mathrm{D}, \mathrm{E}$ \\
\hline Harpacticoida & & Protoperidinium sp. & $\mathrm{C}, \mathrm{D}, \mathrm{E}$ \\
\hline Euterpina acutifrons & $\mathrm{C}, \mathrm{D}, \mathrm{E}$ & Diatomacea & \\
\hline Macrosetella sp. & E & Chaetoceros sp. & $\mathrm{D}$ \\
\hline Microsetella sp. & $\mathrm{C}, \mathrm{D}, \mathrm{E}$ & Discoid diatom & $\mathrm{C}, \mathrm{D}$ \\
\hline
\end{tabular}

\section{LITERATURE CITED}

Carlton JT (1985) Transoceanic and interoceanic dispersal of coastal marine organisms: the biology of ballast water. Oceanogr Mar Biol Annu Rev 23:313-371

Carlton JT (1989) Man's role in changing the face of the ocean: biological invasions and implications for conservation of near-shore environments. Conserv Biol 3(3):265-273

Carlton JT (1996) Pattern, process, and prediction in marine invasion ecology. Biol Conserv 78:97-106

Carlton JT (ed) (1999) Ballast water: ecological and fisheries implications. International Council for the Exploration of the Sea, ICES Coop Res Rep No. 224

Carlton JT, Geller JB (1993) Ecological roulette: the global transport of nonindigenous marine organisms. Science 261(5117):78-82

Carlton JT, Navarret AM, Mann R (1982) Biology of ballast water: the role of ballast water in the transoceanic dispersal of marine organisms. Final Project Report, Nat Sci Found Division of Applied Research (Biology), Woods Hole Oceanographic Institute, Woods Hole, Massachusetts, Report Number DAR 800840
Chu KH, Tam PF, Fung CH, Chen QC (1997) A biological survey of ballast water in container ships entering Hong Kong. Hydrobiologia 352:201-206

Cohen AN, Carlton JT (1998) Accelerating invasion rate in a highly invaded estuary. Science 279:555-557

Cordell JR, Morrison SM (1996) The invasive Asian copepod Pseudodiaptomus inopinus in Oregon, Washington, and British Columbia estuaries. Estuaries 19(3):629-638

Elton CS (1958) The ecology of invasions by animals and plants. Methuen and Co. Ltd., London

Galil B, Hülsmann N (1997) Protist transport via ballast water-biological classification of ballast tanks by food web interactions. Eur J Protistol 33:244-253

Gollasch S, Dammer M, Lenz J, Andres HG (2000) Survival of tropical ballast water organisms during a cruise from Indian Ocean to the North Sea. J Plankton Res 22(5): 923-937

Hallegraeff GM (1998) Transport of toxic dinoflagellates via ships' ballast water: bioeconomic risk assessment and efficacy of possible ballast water management strategies. Mar Ecol Prog Ser 168:297-309

Hallegraeff GM, Bolch GC (1991) Transport of toxic dinofla- 
gellate cysts via ships' ballast water. Mar Poll Bull 22(1): $27-30$

Hwang JS, Turner JT (1995) Behaviour of cyclopoid, harpacticoid, and calanoid copepods from coastal waters of Taiwan. Mar Ecol 16(3):207-216

IMO (International Maritime Organization) (1991) International guidelines for preventing the introduction of unwanted aquatic organisms and pathogens from ships' ballast water and sediment discharges. Marine Environmental Protection Committee, Resolution (50)31 (July 4, 1991); adopted by International Maritime Organization, Resolution A774(18) (Nov. 4, 1993)

Jelmert A, van Leeuwen J (2000) Harming local species or preventing the transfer of exotics? Possible negative and positive effects of using zinc anodes for corrosion protection of ballast water tanks. Water Res 34(6): 1937-1940

Lavoie DM, Smith LD, Ruiz GM (1999) The potential for intracoastal transfer of non-indigenous species in the ballast water of ships. Estuar Coast Shelf Sci 48:551-564

Levings CD, Piercey GM, Galbraith M, Jamieson GS (1999) Analyses of invertebrate fauna in ballast water collected in ships arriving at British Columbia ports, especially those from the western Pacific. Final Draft Report, Fisheries and Oceans Science Branch, West Vancouver Laboratory, 4160 Marine Drive, West Vancouver, B.C., Canada V7V $1 \mathrm{~N} 6$

Locke A, Reid DM, van Leeuwen HC, Sprules WG, Carlton JT (1993) Ballast water exchange as a means of controlling dispersal of freshwater organisms by ships. Can J Fish Aquat Sci 50(10):2086-2093

NRC (National Research Council) (1996) Stemming the tide: controlling introductions of nonindigenous species by ships' ballast water. National Academy of Sciences, Washington, DC

Orsi JJ, Ohtsuka S (1999) Introduction of the Asian copepods Acartiella sinensis, Tortanus dextrilobatus (Copepoda: Calanoida), and Limnothoina tetraspina (Copepoda: Cyclopoida) to the San Francisco estuary, California, USA. Plankton Biol Ecol 46(2):128-131

Parker IM, Simberloff D, Lonsdale WM, Goodell K, Wonham M, Kareiva PM, Williamson MH, Von Holle B, Moyle PB, Byers JE, Goldwasser L (1999) Impact: assessing the ecological effects of invaders. J Biol Inv 1(1):3-19

Pechenik J (2000) Larval experience can influence invasion potential for marine invertebrates. In: Pederson J (ed) Proceedings of the First National Conference, January 24-27, 1999. Massachusetts Institute of Technology Sea Grant College Program, Cambridge, MA, USA, p 89-93

Pollard DA, Hutchings PA (1990) A review of exotic marine organisms introduced to the Australian region. II. Invertebrates and algae. Asian Fish Sci 3:223-250

Rice WR (1989) Analyzing tables of statistical tests. Evolution 43(1):223-225

Rigby G, Hallegraeff G (1994) The transfer and control of harmful marine organisms in shipping ballast water:

Editorial responsibility: Otto Kinne (Editor), Oldendorf/Luhe, Germany behavior of marine plankton and ballast water exchange trials on the MV 'Iron Whyalla'. J Mar Environ Eng 1: 91-110

Ruiz GM, Hines AH (1997) The risk of nonindigenous species invasion in Prince William Sound associated with oil tanker traffic and ballast water management: pilot study. Regional Citizens' Advisory Council of Prince William Sound, Valdez, Alaska, RCAC Report no. 632f.97.1

Ruiz GM, Carlton JT, Grosholz ED, Hines AH (1997) Global invasions of marine and estuarine habitats by non-indigenous species: mechanisms, extent, and consequences. Am Zool 37:621-632

Ruiz GM, Fofonoff PF, Carlton JT, Wonham MJ, Hines AH, Cohen A (2000) Invasion of coastal marine communities in North America: patterns and processes. Annu Rev Ecol Syst 31:481-531

Sautour B, Castel J (1993) Importance of microzooplanktonic crustaceans in the coastal food chain: Bay of MarennesOleron, France. Oceanol Acta 21(1):105-112

Smith LD, Lavoie DM, Ruiz GM, Galil BS (2000) Changes in ballast water biota during intracoastal and transoceanic voyages. In: Pederson J (ed) Proceedings of the First National Conference, January 24-27, 1999. Massachusetts Institute of Technology Sea Grant College Program, Cambridge, MA, USA, p 278-281

Smith LD, Wonham MJ, McCann LD, Ruiz GM, Hines AH, Carlton JT (1999) Invasion pressure and inoculant survival in a ballast-flooded estuary. J Biol Inv 1(1):67-87

Steinberg DK, Silver MW, Pilskaln CH, Coale SL, Paduan JB (1994) Midwater zooplankton communities on pelagic detritus (giant larvacean houses) in Monterey Bay, California. Limnol Oceanogr 39(7):1606-1620

Subba Rao DV, Sprules WG, Locke A, Carlton JT (1994) Exotic phytoplankton from ships' ballast waters: risk of potential spread to mariculture sites on Canada's east coast. Can Data Rep Fish Aquat Sci No. 937

Vermeij G (1996) An agenda for invasion biology. Biol Conserv 78(1-2):3-9

Wilcove DS, Rothstein D, Dubow J, Phillips A, Losos E (1998) Quantifying threats to imperiled species in the United States. Bioscience 48(8):607-615

Williams RJ, Griffiths FB, van der Wal EJ, Kelly J (1988) Cargo vessel ballast water as a vector for the transport of nonindigenous marine species. Estuar Coast Shelf Sci 26(4): 409-420

Williamson M (1996) Biological invasions. Chapman and Hall, New York

Wonham MJ, Carlton JT, Ruiz GM, Smith LD (2000) Fish and ships: relating dispersal frequency to success in biological invasions. Mar Biol 136:1111-1121

Wonham MJ, Walton WC, Frese AM, Ruiz GM (1996) Transoceanic transport of ballast water: biological and physical dynamics of ballasted communities and the effectiveness of mid-ocean exchange. U.S. Fish and Wildlife Service and Compton Foundation Final Report (unpubl.), available from the authors

Submitted: April 14, 2000; Accepted: September 29, 2000 Proofs received from author(s): April 10, 2001 